\title{
Article
}

\section{Editorial: Labour and Landscape}

Kallio, Kalle and Mansfield, Nicholas

Available at http://clok.uclan.ac.uk/13776/

Kallio, Kalle and Mansfield, Nicholas ORCID: 0000-0002-5498-9710 (2013)

Editorial: Labour and Landscape. International Journal of Heritage Studies, 19 (5). 401-407.. ISSN 1352-7258

It is advisable to refer to the publisher's version if you intend to cite from the work.

For more information about UCLan's research in this area go to

http://www.uclan.ac.uk/researchgroups/ and search for < name of research Group>.

For information about Research generally at UCLan please go to http://www.uclan.ac.uk/research/

All outputs in CLoK are protected by Intellectual Property Rights law, including Copyright law. Copyright, IPR and Moral Rights for the works on this site are retained by the individual authors and/or other copyright owners. Terms and conditions for use of this material are defined in the policies page.

\section{CLoK}

Central Lancashire online Knowledge www.clok.uclan.ac.uk

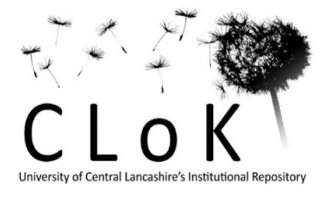




\title{
Editorial: Labour and Landscape
}

\author{
Kalle Kallio
}

The Finnish Labour Museum, Tampere, Finland

Museum Director Kalle Kallio

The Finnish Labour Museum

Väinö Linnan aukio 8

33210 Tampere

Finland

kalle.kallio@tyovaenmuseo.fi

$+358407167520$

Kalle Kallio has been Director of the Finnish Labour Museum since 2005. In 2010, he was elected as a chair of WORKLAB - International Association of Labour Museums. He has written several essays mostly concerning museum learning and the social mission of museums. He also teaches museum studies at the University of Tampere.

\section{Nick Mansfield}

UCLan, Preston, UK

Dr Nick Mansfield, School of Education and Social Sciences, UCLan, Preston, PR1 2HE, UK, NMansfield1@uclan.ac.uk

Since 2010, Senior Research Fellow in History at the University of Central Lancashire, Preston, prior to that he was Director of the People's History Museum, Manchester for 21 years. He is author of English Farmworkers and local patriotism, 1900-1930 and over 40 other publications and the leading UK practitioner in using material culture as historical evidence. 


\section{Editorial: Labour and Landscape}

\section{Introduction}

This special issue of the journal concentrates on labour, especially organised labour, the way it interacts with its society and landscape and how this is interpreted by related museums and heritage organisations. Museums of this type have been cooperating across national boundaries for many years through WORKLAB - the International Association of Labour Museums (www.worklab.info). Most of the papers in this issue were first presented at WORKLAB's 2010 conference hosted by the Finnish Labour Museum in Tampere, Finland. Several were presented by long serving directors of museums of labour and WORKLAB members who are nearing the end of their careers and represent several decades of accumulated knowledge and experience. This editorial seeks to give context to these papers, firstly by outlining how working class people have interacted with museums in the last two centuries and then by sketching the development of museums about working class people their environment and institutions. This special edition showcases research projects and exhibitions mounted by WORKLAB members. In addition, there is a case study on a joint attempt to develop a Proposition for UNESCO's World Heritage List on workers' assembly halls. Overall, the papers collected here demonstrate that labour museums are well equipped to respond to the multiple challenges the twenty first century will pose to museums pursuing progressive social agendas.

\section{Revolution, museums and the working class}


The idea of an open and public museum is commonly traced back to the French revolution. Louvre Palace's Grand Gallery was opened in 1793 and renamed the Museum Français as a revolutionary symbol, giving the French people free access (in theory) to their national art and treasure. Despite this, both in France and the rest of Europe, most public museums have been repeatedly criticized for neglecting audiences, turning inwards and propagating the values and aesthetics of the educated and civilised elite. At their heart, museums as institutions were born in royal or aristocratic environments and though many absorbed bourgeois concerns and collections during the Victorian period, museum visiting was slow to become an established habit in the lives of ordinary people (Abt 2011, p. 128-129).

The relation between workers and European museums has been especially tensioned. According to Bennett (2004, p. 422-423), museums in the early nineteenth century had a limited conception of their visiting public. The British Museum, for example, demanded that visitors submit their credentials for inspection before gaining entrance. During the radical Chartist agitation in London 1848, the British Museum was even fortified and museum staff were armed with muskets and provisions for a potential three-day siege. In the early nineteenth century, museums generally feared the actions of the disturbing mob and thought that visiting crowds of working people would be difficult to keep in order (Bennett 2004, p. 422-425).

This reserved attitude started to change during the world exhibitions, which were tremendously popular. The Great Exhibition in London in 1851 attracted over six million visitors including considerable numbers of working class visitors brought in by special excursion trains (Wolmar 2008, p. 112-113). Bennett (2004) recognises the opening of the South Kensington Museum (later the Victoria and Albert Museum and the Science Museum) in 1857 as a turning point in the development of British 
museum policy. The South Kensington Museum was a direct descendant of the Great Exhibition, both as a recipient of collections originally displayed at the Crystal Palace and as a recipient of the considerable profits accumulated (Bennett 2004, p. 424-426).

By the end of the nineteenth century, many museums had already adopted a strong educational role. In an increasingly industrialised and class divided continent, the labour issue was the most important social and political question in many European countries and innovative museums reacted to this, albeit in a patriarchal way. The workers were principally seen as an ignorant and uncivilised mass, but at best they could be educated with art and culture. The South Kensington Museum, for instance, sought consciously to educate skilled working men in good design by displaying the finest applied art collections, in a direct attempt to improve their expertise and knowledge for use in their working lives. In addition, the general insistence on civilized manners and good taste by museums were thought to be qualifications for political liberties in the future, as the right to vote was gradually extended (Coombes 2004, p. 284-285, Bennett 1999, p. 248-251). Curiously, these civilizing efforts of the museums lost their impetus when civil rights in much of Europe were achieved by political action. Within the maturing European states, social and educational issues became the concern of parliaments, adult education services and self help organisations, rather than museums, in the process of fostering nationhood and democracy. Especially within art museums, the aesthetic emphasis already had the upper hand by the turn of the twentieth century. It can be argued that most museums turned inwards for much of the first half of the twentieth century, at least until after the Second World War (O’Neill 2002, p. 25-27). 


\section{The development of museums of labour}

Appreciation of workers' culture and history experienced a real surge in the 1960s and 1970s. This change occurred at around the same time in different Western European countries, and its origins can be traced to universities that were by then filled with the ideologically awakening baby boom generation. New questions arising in the academic fields of history, ethnology and sociology inspired scholars, many themselves now of working class origin. Within the labour movement, there was also an increasing interest in the study of working class traditions. This was intensified by the great variety of historical novels and popular films of everyday history, alongside popular scholarly books (such as in Britain, E.P. Thompson's 1963 volume Making of the English Working Class) that had garnered new audiences, which were much wider than the traditional academy (Kallio 2010, p. 120-121).

The museum sector also underwent an ideological change when the baby boom generation began reforming the institutions. First, the developing welfare state increased the resources of museums, which gave them better opportunities to collect material from relatively recent industrial and social history (Sjöberg-Pietarinen 2004, p. 51-52). This process gained political support from museum funders as well as new audiences interested in the process of industrialization and the birth of the working class. This intensified, curiously, as the older heavy industry declined in the post war world. For example, in Finland, people thought that distinctive working class life and culture was changing rapidly and in danger of disappearing with the blurring of class within society. So the changing interests of the public encouraged museums to focus on the history of everyday life and labour heritage. In addition, traditional presentation of heritage was often felt completely outdate (Sjöberg-Pietarinen 2004, p. 54-56, Kallio 2010, p. 121). . 
The diversity of this development can be roughly described within a typology of four categories of labour museums. Museums on work and industry form the largest group, which seems to be continuing to grow. These museums are often located in former industrial buildings, which have had special importance locally. They often focus on corporate history, the work carried out in the factory, its products and the production process, while the everyday lives of the workers and the local community often have a secondary role. The second category includes the museums of workers' housing. They are usually open-air museums and approach labour heritage from the perspective of the everyday experience. These museums mostly follow similar patterns with rooms decorated as homes of an imaginary or a real working family. The third group consists of museums of the labour movement. Trade unions, co-operative movements and some political parties have founded their own institutions since the Second World War, some associated with the birth places or homes of pioneering labour leaders. These museums and 'memory rooms' are mostly small and some have been short-lived as they struggle to appeal to more than specialist visitors.

Museums that combine the perspectives of work and industry, workers' housing and the labour movement can be defined as integrated labour museums. For example, in Nordic countries, this fourth category was born in 1983 when Arbejdermuseet was opened in Copenhagen. It was followed by Rjukan, in Norway, in 1988, then Sweden's Norrköping, in 1991 and Tampere, Finland in 1993. The development from small museums with limited interests into national and professionally run labour museums took some decades in many countries.

Labour museums founded their own organisation in 1997. WORKLAB, the International Association of Labour Museums was founded by six European labour 
museums. WORKLAB's aims were promoting the collection, research and interpretation of labour and workers' culture, providing a forum for communication, co-operation and exchange of information between museums and others concerned with workers' history and co-operation with other organisations within the heritage sector. In fifteen years of its existence, WORKLAB has grown from six labour museums into a global network of thirty museums. Member organisations represent the wide variety of all those categories presented above. The organisation includes not only museums of labour, but also museums generally interested in social and industrial history and different aspects of work and everyday living. All these museums share a social perspective to cultural heritage, which separates them from the mainstream museum sector. However, many WORKLAB members are poorly funded compared, particularly when compared with other areas of the museum sector within their individual countries. Nonetheless, WORKLAB members have benefited by working co-operatively together. The first example of this was the project Migration, Work and Identity (2000-2004), a four-year programme of joint exhibitions, conferences and publications on migrant communities within eight European cities. This was underpinned by a joint touring exhibition, and was made possible by European Union Culture 2000 funding. The latest WORKLAB project, Work with Sounds, will start in September 2013, also funded by the European Union.

\section{The context of the papers in this special issue}

In 2010, WORKLAB organised a joint conference with TICCIH - the International Committee for the Conservation of the Industrial Heritage and ICOHTEC - the International Committee for the History of Technology History in Tampere, Finland. 
Some of the papers presented in the conference are included in this special issue of the Journal. The authors in this issue represent different labour or industrial museums, academics and labour organisations.

The overarching theme of this issue is labour and landscape. Four papers concentrate on labour monuments and especially workers' meeting halls. Peter Ludvigsen's lead article 'Workers' assembly halls as a proposition for UNESCO's World Heritage raises an important issue of labour heritage as world heritage. It is followed by an discussion by Nick Mansfield and Myna Trustram of the history and interpretation of the buildings of the British labour movement. Holger Gorr gives a political overview of German Volkshauser or union houses and Anke Hoffsten continues this theme with a discussion of the way the architectural aspects of these buildings represent an early phase of modernity. The last two papers in this issue are case studies that examine the relationship of workers to social institutions. Dagmar Kift researches post war mining culture and regional identity in the Ruhr and Rita Müller concludes this issue with an overview of technical and industrial museums in Germany in the twenty first century.

Peter Ludvigsen was the long serving and founding director of the Arbejdermuseet (Workers' Museum) in Copenhagen and has observed that UNESCO’s World Heritage List does not have a single cultural example from industrial workers' history or culture. He argues for the need to rectify that omission and suggests that the category of Workers' Assembly Halls, found in the Nordic countries, France, Germany, Australia and the USA, makes a good first case study for potential inclusion to commence rectifying the imbalance on the World Heritage List. After a suggestion from the Danish Heritage Board, the Workers' Museum has, since 2009 , inventoried a large number of workers meeting halls worldwide with the 
purpose of suggesting a selection to a transnational serial nomination for the Tentative List. After a comprehensive review, nine workers' meeting halls erected between 1874 and 1937 have been selected, all are nationally listed, have a high degree of integrity and are considered good examples of these monuments to the history and culture of the industrial workers. Together they illustrate important developments within the Western international labour movement of the industrial period.

Nick Mansfield, director between 1989 and 2010 of the Manchester based People's History Museum, the foremost museum of labour in the UK. Both he and his former colleague, Myna Trustram, are now academic researchers. Their paper 'Remembering the buildings of the British labour movement: an act of mourning?' outlines the historical development of the wide variety of the buildings of the British labour movement. Hitherto, British labour activists, historians and heritage professionals have focused on the artefacts and archives as opposed to the many historic buildings of the labour movement. The narrative closely follows the course of the industrial revolution and the accompanying development of the labour movement from its beginnings in the eighteenth century. Examples cover a wide range including the artisan trade societies, utopian Owenite socialist settlements and purpose-built radical and trade union premises. The paper concludes with a consideration of why these buildings are relatively neglected. It suggests that one reason may lie in the popular labour movement sentiment of 'don't mourn, organise', that is, don't spend valuable time looking back on what has been lost but set about improving life for workers here and now.

Union official Holger Gorr tackles the subject of Volkshaeuser in Germany, with a historical overview from 1900 to the present. A Volkshaus, or union house, is the German type of managed workers' assembly hall, often combined with a hotel, a 
restaurant and offices. These houses were a major component of the socialist workers' movement. In Germany, the socialist workers' movement began to grow from the 1890s, but suffering from the oppression of the autocratic Bismarckian state, it had problems finding suitable meeting places. Thus, from the turn of twentieth century, the unions established their own assembly halls that absorbed the German 'tavern culture' and provided high quality facilities missing from the poor living conditions of most of the working class. The Volkshaeuser were crucial for the formation of working class culture, but their history closely followed the political cycle of the labour movement. The November revolution of 1918 precipitated an upswing in membership, as the labour movement reached its peak. The enemies of the labour movement attacked the Volkshaeuser for their symbolic meaning while they were simultaneously stormed as part of the Nazi coup on May 2, 1933. The unions were banned, their assets, including the Volkshaeuser, were seized. The heyday of the rich political and cultural life of the Volkshaeuser disappeared overnight and many of the houses were damaged during the Second World War. Collectively administered, Volkshaeuser and their associated shared culture, lacked meaning for the post war generation of German workers. Their large meeting halls were superseded by other forms of democracy and they never regained their former significance within German democracy.

Anke Hoffsten continues the examination of German Volkshaeuser in more detail. She concentrates on the commissioning and the specific characteristics of the builders, the planners, the functions and uses of the buildings and the aesthetic and ideal aspects of the architecture. The specialised features of the architecture of the workers' assembly halls are illustrated by selected examples and placed in the context of the development of architecture in the early period of modernism and its related 
discourses. The paper discusses the historical preservation of a few well-preserved examples as national monuments.

Dagmar Kift's paper reports on the research she undertook for a project at the LWL-Industriemuseum Dortmund, Germany. In an exhibition and its associated events and publications, she looks at cultural features and developments in the Ruhr area coalmining industry between the end of the Second World War and the onset of the structural crisis in 1966 . The paper outlines older mining traditions, amateur worker-artists, pop music culture and high art. These were features common to both the industry and the region, and were promoted by both in their search for a new identity. The article pursues a cross-cultural approach and suggests that 're-using the industrial past' in such a way might help to modernise labour and industrial history, help facilitate international comparisons and contribute to a differentiated picture of our past and present.

Rita Müller's contribution explores how industrial and technical museums are challenged by de-industralization, and the ways such museums may expand their audiences. Müller illustrates the importance of the inclusion of social context, particularly issues such as migration, Europeanisation and globalisation in the displays developed in industrial and technical museums. She illustrates how these museums have attempted to compete for new audiences without losing sight of their overall educational mandate and concludes by suggesting that new foundations like the Ruhr Museum - opened in 2010 - put a high priority on interactive elements and aggressive marketing. The definition of 'museum' has broadened, so that many new museums are a hybrid of cultural heritage site, science centre, archaeological site and tourist destination. 
Developments as described by Muller are paralleled by recent openings in other European museums of labour - such as the People's History Museum in Manchester, the Finnish Labour Museum in Tampere, and the Workers' Museum in Copenhagen. All of these take the concept of labour museums to a modern, substantial, significant and confident height, which augurs well for their ability to meet the challenges of ever faster economic, political and cultural change.

\section{References}

Abt, J., 2011. The Origins of the Public Museum. In: Macdonald, S., ed. A Companion to Museum Studies. $1^{\text {st }}$ edition 2006. Chichester: Wiley-Blackwell, 115-134.

Bennett, T., 1999. That those who run may read. In: Hooper-Greenhill, E., ed. The Educational Role of the Museum. $1^{\text {st }}$ edition 1994. London: Routledge, 241253.

Bennett, T., 2004. The Exhibitionary Complex. In: Preziosi, D. and Farago, C., eds. Grasping the World. The Idea of the Museum. Aldershot: Ashgate, 413-441.

Coombes, A., 2004. Museums and the Formation of National and Cultural Identities. In: Preziosi, D. and Farago, C., eds. Grasping the World. The Idea of the Museum. Aldershot: Ashgate, 278-297.

Kallio, K., 2010. Labour Heritage and Identities in Tampere. In: Rantanen, K., ed. Living Industrial Past. Perspectives to industrial history in the Tampere region. Tampere: Museum Centre Vapriikki and the Finnish Labour Museum Werstas, 110-135

O’Neill, M., 2002. The good enough visitor. In: Sandell, R., ed. Museums, Society, Inequality. London: Routledge, 24-40.

Sjöberg-Pietarinen, S., 2004. Museer ger mening. Friluftsmuseerna Klosterbacken och Amuri som representationer. Åbo: Åbo Akademi. Also available from: http://urn.fi/URN:ISBN:951-765-158-9

Thompson, E.P., 1963. The Making of the English Working Class. London: Victor Gollancz.

Wolmar, C., 2008. Fire \& Steam. How the Railways Transformed Britain. London: Atlantic Books. 